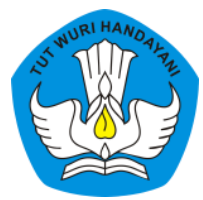

Page: 867-886

\title{
PEMANFAATAN LAPTOP GADGET DAN PRINTER (LAGA PINTER) SEBAGAI MEDIA PEMBELAJARAN PADA MATERI SEGI EMPAT SISWA KELAS VII K SMP NEGERI 5 KENDARI
}

\author{
Asri Azis \\ Sekolah Menengah Pertama Negeri 5 Kendari, Sulawesi Tenggara, Indonesia \\ Contributor Email: asriazis668@gmail.com
}

Received: Feb 15, 2021

Accepted: Jul 2, 2021

Published: Nov 30, 2021

Article Url: https:/ / ojsdikdas.kemdikbud.go.id/index.php/didaktika/article/view/342

\begin{abstract}
Laga Printer is a learning media which covers laptop, gadget, and printer as a solution for students' learning difficulties in working on mathematic problems on types and characteristics of rectangular. The aim of using Laga Printer is to improve students' learning efficacyat class VII K SMP Negeri 5 Kendari on types and characteristics of rectangular. The use of Laga Printer in the learning process was designed in the form of classroom action research method which was carried out in two meetings. Instruments of this study covers achievement test and questionnaires. This study showed that from 30 students assigned to the test,26 students $(86.66 \%)$ achieved mastery learning with scores $\geq 73$. On skill aspect, 19 students (63.33\%) had very good category and 7 students (23.33\%) had good category. Students' questionnaires analysis pointed out that 25 students $(83.33 \%)$ were very satisfied and 3 students $(10.00 \%)$ were satisfied with Laga Printer. The practical value of 78 showed that Laga Printer is a practical learning media. Thus, this study concludes that the use of Laga Printer as a learning media can make students learn better and improve their learning efficacyat class VII K SMP Negeri 5 Kendari.
\end{abstract}

Keywords: Laga Printer; Learning Media; Rectangle. 


\begin{abstract}
Abstrak
Laga printer adalah media pembelajaran berupa perangkat ICT yang terdiri atas laptop, gadget, dan printer sebagai solusi mengatasi kesulitan siswa pada materi Jenis dan Sifat Segi Empat.Tujuan penggunaan Laga Printer sebagai media pembelajaran berbasis ICT adalah untuk membelajarkan dan meningkatkan hasil belajar siswa kelas VII K SMP Negeri 5 Kendari pada materi Memahami Jenis dan Sifat Segi Empat. Penggunaan "laga printer" tersebut dikemas dalam bentuk penelitian tindakan kelasyang dilaksanakan selama dua kali pertemuan. Instrumen yang digunakan dalam penelitian ini adalah tes hasil belajar dan amgket. Hasil penelitian menunjukkan bahwa dari 30 orang siswa terdapat 26 siswa $(86,66 \%)$ yang tuntas belajar dengan nilai $\geq 73$ dan hanya 4 siswa $(13,33 \%)$ yang belum tuntas belajar. Padsa aspek keterampilan terdapat 19 siswa (63,33\%) kategori sangat mahir dan 7 siswa (23,33\%) kategori mahir. Untuk tingkat kepuasan siswa terhadap penggunaan Laga Printer dalam pembelajaran terdapat 25 siswa (83,33\%) dengan kriteria sangat baik, 3 siswa (10,00\%) dengan kriteria baik. Laga Printer juga tergolong praktis dengan nilai praktikalitas sebesar 78. Dengan demikian disimpulkan bahwa penggunaan Laga Printer sebagai media pembelajaran pada materi Memahami Jenis dan Sifat Segi Empat dapat membelajarkan dan meningkatkan hasil belajar siswa kelas VII K SMP Negeri 5 Kendari.
\end{abstract}

Kata Kunci: Laga Printer; Media Pembelajaran; Segiempat.

\title{
A. Pendahuluan
}

Kurikulum merupakan suatu proses pendidikan terhadap kebutuhan masyarakat dan bangsa dalam membangun generasi muda bangsanya. Kurikulum 2013 yang berlandaskan Undang-undang Nomor 20 Tahun 2003 tentang Sistem Pendidikan Nasional, Peraturan Pemerintah Nomor 19 Tahun 2005, dan Peraturan Menteri Pendidikan Nasional Nomor 22 dan 23 Tahun 2006, merupakan salah satu strategi pembangunan pendidikan nasional. Kurikulum ini mengarahkan siswa untuk menjadi manusia yang berdaya saing global dan mampu mengatasi tantangan zaman yang semakin kompleks dengan berbekal kecerdasan spiritual, emosional dan ilmu pengetahuan. Manusia Indonesia yang seperti ini seharusnya tidak muncul karena hasil seleksi alam, namun karena hasil didikan pada tiap jenjang satuan pendidikan dengan kurikulum sebagai pengarahnya.

Rendahnya mutu pendidikan matematika tersebut bukan hanya disebabkan pelajaran matematika yang sulit, melainkan juga disebabkan oleh beberapa faktor lain seperti siswa itu sendiri, guru, strategi pembelajaran, 
maupun lingkungan belajar yang saling berhubungan satu sama lain. Faktor dari siswa yaitu kurangnya pemahaman konsep siswa terhadap materi yang diajarkan. Faktor lain yaitu adanya anggapan/asumsi yang keliru dari guruguru yang menganggap bahwa pengetahuan manusia itu dapat dipindahkan secara utuh dari pikiran guru ke pikiran siswa. Akan tetapi, dalam perkembangan seperti ini, guru dituntut agar tugas dan peranannya tidak lagi sebagai pemberi informasi melainkan sebagai pendorong belajar agar siswa dapat mengonstruksi sendiri pengetahuan matematika yang dimilikinya.

Zimmerman (2005) yang menyatakan bahwa motivasi merupakan faktor penting dalam proses belajar siswa. Motivasi merupakan penunjang bagi siswa dalam rangka melaksanakan aktivitas belajar secara optimal. Ini dimaksudkan untuk merangsang daya kreativitas dan kemauan siswa dalam mengikuti kegiatan belajar. Motivasi belajar dapat dikelompokkan menjadi tiga bagian yaitu motivasi tinggi, sedang, dan rendah. Siswa yang memiliki motivasi belajar tinggi akan mengikuti proses pembelajaran dengan antusias, dan lebih baik dibandingkan dengan siswa yang memiliki motivasi belajar yang rendah. Oleh karena itu, sangat penting menggelompokkan siswa berdasarkan motivasi belajar agar mengetahui sejauh mana tingkat motivasi siswa yang akan mengikuti pembelajaran.

Selanjutnya Ratumanan (2004) mengemukakan bahwa motivasi dapat berfungsi sebagai pendorong usaha belajar dan pencapaian hasil belajar yang lebih baik. Motivasi dapat mengarahkan siswa dalam belajar untuk mencapai tujuan atau cita-citanya. Motivasi dapat berperan dalam menyeleksi perbuatan siswa, apa yang harus dilakukan, dan apa yang harus dikesampingkan.

Sudjana (2005) mengemukakan bahwa hasil belajar adalah kemampuankemampuan yang dimiliki siswa setelah ia menerima pengalaman belajar. Pencapaian hasil belajar tersebut dapat diketahui dengan dengan mengadakan penilaian tes hasil belajar. Penilaian diadakan untuk mengetahui sejauh mana siswa telah berhasil mengikuti pelajaran yang diberikan oleh guru. Di samping itu, guru dapat mengetahui sejauhmana keberhasilan seorang guru dalam proses belajar mengajar di sekolah. 
Matematika mempunyai kegunaan yang sangat penting dalam kehidupan sehari-hari. Disadari atau tidak kebermanfaatan matematika sangat berpengaruh dalam berbagai aspek utama seperti ekonomi, sosial, politik, kesehatan, teknologi, dan pendidikan. Fajar Shodiq dalam makalahnya menyampaikan bahwa NRC (National Research Council, 1989) dari Amerika Serikat telah menyatakan pentingnya matematika dengan pernyataan, "Matematics is the key to opportunity." Matematika adalah kunci ke arah peluangpeluang. Masih menurut NRC, bagi seorang siswa keberhasilan mempelajari matematika akan membuka pintu karir yang cemerlang. Bagi warga negara, matematika akan menunjang pengambilan keputusan yang tepat. Bagi suatu negara, matematika akan menyiapkan warganya untuk bersaing dan berkompetisi di bidang ekonomi dan teknologi.

Mengingat arti pentingnya matematika dalam kehidupan maka pembelajaran matematika diharapkan mampu mewujudkan iklim yang menyenangkan dan penuh gairah, sehingga tercapai tujuan yang diharapkan, yakni kemampuan berpikir sistematis, logis, kritis dengan mengedepankan nilai karakteristik bangsa yang luhur. Setelah siswa dapat berpikir secara sistematis, logis, dan abstrak, diharapkan siswa mampu menggunakan matematika dalam pemecahan masalah, serta melakukan komunikasi dengan menggunakan simbol, tabel, grafik dan diagram yang dikembangkan melalui pembelajaran yang dilakukan secara bertahap dan berkesinambungan. Setelah aspek dan tahapan pembelajaran sudah dilaksanakan maka harapannya adalah diperolehnya hasil belajar yang memuaskan, dalam hal ini pada tingkat sekolah paling tidak sudah memenuhi Kriteria Kentutasan Minimal (KKM) yang telah ditetapkan. Pembelajaran matematika juga diharapkan dapat mendukung tercapainya nilai karakter dan sifat dasar yang saat ini tengah digali kembali setelah terjadinya degradasi moral dan sosial bangsa.

Namun pada kenyataannya proses pembelajaran matematika di SMP Negeri 5 Kendari belum dapat berjalan secara optimal. Pembelajaran matematika cenderung text book oriented, teacher oriented, dan kurang terkait dengan kehidupan sehari-hari siswa. Pembelajaran cenderung abstrak sehingga konsep-konsep akademik sulit dipahami. Akibatnya, hasil belajar matematika belum sesuai harapan. Minat siswa terhadap pelajaran matematika 
sangat rendah. Sebagian besar siswa mengeluh bahwa pelajaran matematika membosankan, tidak menarik bahkan penuh misteri. Ini disebabkan karena pelajaran matematika bagi siswa dirasakan sangat sukar, tidak menarik, dan materi pelajaran yang dipelajari tidak ada kaitannya dengan kehidupan sehari-hari. Kenyataan di atas tidak aneh jika hasil ujian atau ulangan selalu lebih rendah dari mata pelajaran yang lain. Sebagai contoh hasil ujian nasional mata pelajaran matematika SMP Negeri 5 Kendari pada tahun pelajaran 2017/2018 siswa kelas IX diperoleh data nilai rata-rata 3,57, nilai tertinggi 10,00, nilai terendah 1,25, dan standar deviasi 1,21. Jumlah peserta ujian yang mendapat nilai $\geq 4,00$ ada 64 peserta ujian dari 194 peserta ujian atau 32,99 \%. Demikian pula hasil ulangan siswa kelas VII SMP Negeri 5 Kendari pada tahun pelajaran 2017/2018 pada materi Segi Empat yang mendapat nilai $\geq 6,50$ rata-rata berkisar 54,23\% - 64,57\% dari jumlah siswa masih jauh dari batas tuntas secara klasikal.

Dalam tulisan ini penulis mengangkat pokok bahasan yang menjadi masalah seperti halnya pengalaman penulis dalam mengajarkan materi Memahami Jenis dan Sifat Segi Empat. Permasalahannya, siswa mengalami kesulitan dalam materi ini. Berdasarkan hasil analisis penulis, kesulitan ini disebabkan oleh (1) rendahnya pengetahuan yang dimiliki siswa, (2) ketidakmampuan membedakan jenis-jenis dan sifat-sifat segi empat.

Siswa dikatakan mengalami kesulitan dalam belajar matematika apabila tidak mencapai taraf kualitas hasil belajar tertentu berdasarkan tujuan pembelajaran yang hendak dicapai. Ruseffendi (1980) mengatakan bahwa objek yang dapat kita periksa untuk mengetahui penyebab kesulitan siswa dalam belajar adalah materi yang diajarkan, pengajarnya, dan muridnya sendiri. Karena belajar matematika adalah belajar tentang konsepkonsep dan struktur abstrak yang disimbolkan maka dalam belajar matematika konsep-konsep yang ada di dalamnya harus dipahami terlebih dahulu. Dalam matematika, untuk dapat memahami konsep B kita terlebih dahulu harus memahami konsep A. Tanpa memahami konsep A, tidak mungkin a dapat memahami konsep B, karena konsep A itu mendasari konsep B (Hudoyo, 1990). Oleh karena itu, untuk mempelajari suatu materi pokok yang baru, 
pengalaman seseorang dalam belajar materi yang lalu sangat memengaruhi keberhasilan seseorang dalam mempelajari materi yang baru tersebut.

Hal ini sejalan dengan pendapat yang dikemukakan oleh Ruseffendi (1992) bahwa dalam mempelajari matematika harus mengikuti dalil-dalil berikut.

\section{Dalil Penyusunan (Construction Theorem)}

Dalam dalil ini menyebutkan bahwa cara yang paling baik bagi anak untuk belajar konsep atau prinsip dalam matematika adalah dengan mengkonstruksi sebuah representasi dari konsep atau prinsip tersebut.

\section{Dalil Notasi (Notation Theorem)}

Dalam dalil ini disebutkan bahwa representasi dari sesuatu materi matematika akan lebih mudah dipahami oleh siswa apabila di dalam representasi itu digunakan notasi yang sesuai dengan tingkat perkembangan kognitif siswa. Penggunaan notasi yang tepat akan mempermudah ditemukannya penyelesaian untuk berbagai macam soal, prinsip matematika, dan pengembangan berbagai konsep, prinsip, dan prosedur dalam matematika.

\section{Dalil Kekontrasan dan Variasi (Contrast and Variation Theorem)}

Dalam dalil ini menyebutkan bahwa bahwa sesuatu konsep matematika akan lebih mudah dipahami oleh siswa apabila konsep itu dikontraskan dengan konsep-konsep lain, sehingga perbedaan antara konsep itu dengan konsep-konsep yang lain menjadi jelas.

\section{Dalil Pengaitan (Connectivity Theorem)}

Dalam dalil ini disebutkan bahwa setiap konsep, setiap prinsip, dan setiap keterampilan dalam matematika berhubungan dengan konsepkonsep, prinsip-prinsip, dan keterampilan- keterampilan lainnya. Berdasarkan teori tersebut di atas, maka siswa ketika mempelajari materi pokok bahasan segi empat dengan submateri pokok Memahami Jenis dan Sifat Segi Empat sangatlah perlu memperhatikan dalil pengaitan (connectivity theorem).

Sebagai contoh siswa diharapkan menguasai materi Memahami Jenis dan Sifat Segi Empat karena materi ini merupakan materi prasyarat 
jika siswa akan mempelajari materi-materi yang lainnya. Secara garis besar, permasalahan-permasalahan tersebut antara lain (1) hasil belajar siswa pada materi Memahami Jenis dan Sifat Segi Empat masih sangat rendah; (2) Guru masih menggunakan metode konvensional dalam pembelajaran matematika; dan (3) Guru tidak menggunakan media pembelajaran yaitu memanfaatkan perangkat ICT sebagai media pembelajaran yang dekat dengan kehidupan siswa.

Media pembelajaran berbasis ICT adalah alat yang digunakan dalam proses pembelajaran dengan memanfaatkan teknologi informasi atau TIK (Teknologi Informasi dan Komunikasi). Dengan berkembangnya ICT maka berkembang pula sistem pendidikan, baik dari tingkat dasar sampai tingkat pendidikan tinggi. Berbagai cara dan media telah dikenalkan dan digunakan dalam proses belajar mengajar dengan tujuan agar semakin banyak guru yang memberikan kreatifitas dalam pengajaran dan dapat menghasilkan pembelajaran yang lebih bermakna tentunya akan meningkatkan mutu pendidikan. Dengan bantuan media komputer diharapkan para siswa akan lebih mudah menyerap informasi dan pelajaran (Pulungan, 2017).

Dalam proses belajar mengajar sangat sering ditemui beberapa mata pelajaran yang sangat abstrak atau sulit dimengerti. Oleh sebab itu, visualisasi pelajaran yang sulit tersebut membuat siswa untuk memahaminya. Media pembelajaran berbasis ICT menurut Suryani (2015) di antaranya teknologi komputer, multimedia, telekomunikasi, dan jaringan komputer. Untuk meningkatkan kualitas pembelajaran matematika di kelas, diperlukan pengembangan materi pembelajaran yang berkualitas. Jika diamati pada buku pelajaran matematika kelas VII masih banyak yang menggunakan penalaran deduktif sehingga ada keluhan yang dialami siswa dalam mempelajari materi dari buku tersebut yakni susah memahami konsep matematika. Selain itu, materi yang disajikan kurang ada keterkaitan antara pembelajaran matematika di sekolah dengan dunia nyata (real) dan kehidupan sehari-hari siswa sehingga menjadi mata pelajaran yang sulit dan ditakuti siswa (Diba et al, 2009).

Dengan adanya fasilitas media pembelajaran maka tradisi lisan dan tulisan yang dilakukan dalam proses pembelajaran selama ini dapat 
diperkaya dengan berbagai media pembelajaran. Dengan adanya media pembelajaran, pendidik dapat menciptakan berbagai situasi kelas, menentukan metode pengajaran yang akan dipakai dalam situasi yang berbeda dan menciptakan iklim dengan emosional yang sehat di antara siswa. Dengan demikian proses pembelajaran dapat ringkas dan asing (remote) sifatnya menjadi konkrit dan mudah dimengerti oleh siswa. Bila alat atau media pembelajaran ini dapat difungsikan secara tepat dan proporsional, maka proses pembelajaran akan dapat berjalan secara efektif.

Laga Printer (Laptop - Gadget - Printer) merupakan alat/benda yang tidak asing lagi bagi kehidupan siswa. Sebagian besar siswa telah memiliki dan pernah menggunakannya dalam kehidupan sehari-hari. Menurut Kamus Besar Bahasa Indonesia (KBBI) pengertian laptop adalah komputer pribadi yang agak kecil, yang dapat dibawa-bawa dan dapat ditempatkan dipangkuan pengguna, terdiri atas satu perangkat yang mencakupi papan tombol, layar tampilan, mikroprosesor, biasanya dilengkapi dengan baterai yang dapat di isi ulang. Fungsi dan kegunaan laptop antara lain mengetik dan membuat presentasi, media hiburan, untuk mendesain, mengedit foto dan video, alat komunikasi, menyimpan data penting, dan memudahkan pekerjaan atau aktivitas.

Menurut Kamus Besar Bahasa Indonesia (KBBI) edisi ke V (lima) gadget adalah nama lain dari gawai yaitu peranti elektronik atau mekanik dengan fungsi praktis. Gadget/ gawai memiliki beberapa fungsi antara lain untuk (a) memperlancar komunikasi, (b) mengakses informasi, (3) wawasan bertambah, (4) hiburan, dan (5) gaya hidup. Pengertian printer adalah perangkat keras komputer (hardware) yang berfungsi untuk mencetak dokumen yang ada dalam komputer.

Berdasarkan hal tersebut, penulis berupaya membelajarkan dan meningkatkan hasil belajar siswa melalui pemanfaatan laptop, gadget dan printer yang di singkat dengan nama Laga Printer sebagai media pembelajaran berbasis ICT dalam pembelajaran Matematika pada materi Memahami Jenis dan Sifat Segi Empat siswa kelas VII K SMP Negeri 5 Kendari.

Rumusan masalah penelitian ini adalah apakah penggunaan Laga Printer sebagai media pembelajaran berbasis ICT pada materi Memahami 
Jenis dan Sifat Segi Empat dapat meningkatkan hasil belajar siswa di kelas VII K SMP Negeri 5 Kendari? Tujuan penelitian ini adalah menggunakan Laga Printer sebagai media pembelajaran berbasis ICT untuk membelajarkan dan meningkatkan hasil belajar siswa kelas VII K SMP Negeri 5 Kendari pada materi Memahami Jenis dan Sifat Segi Empat sesuai dengan tujuan pembelajaran yang hendak dicapai oleh siswa.

Manfaat penelitian bagi siswa antara lain (1) meningkatnya kemampuan siswa untuk memahami konsep tentang materi Memahami Jenis dan Sifat Segi Empat, (2) meningkatkan kemampuan berpikir kritis sehingga mampu mengaitkan isi materi pelajaran dengan kehidupan sehari-hari, dan (3) mampu menggunakan dan mengoperasikan laptop, gadget dan printer sebagai media pembelajaran dalam menyelesaikan tugas kelompok. Hasil penelitian memberikan manfaat kepada guru antara lain (1) memberi ide inovatif bagi guru lain agar selalu mengembangkan media pembelajaran, (2) guru dapat mengetahui variasi strategi belajar mengajar yang dapat digunakan sebagai salah satu usaha untuk meningkatkan hasil belajar siswa dan sesuai dengan materi pelajaran, dan (3) memberikan masukan kepada guru agar terampil dalam menyajikan program pembelajaran dan mengelola proses pembelajaran. Manfaat bagi Musyawarah Guru Mata Pelajaran (MGMP) Matematika antara lain (1) memberikan informasi bahwa salah satu strategi agar siswa aktif dalam belajar adalah dengan menerapkan pembelajaran Problem Based Learning dengan memanfaatkan media berbasis ICT seperti laptop, gadget dan printer, dan (2) sebagai bahan kajian dalam mengembangkan proses pembelajaran di kelas.

\section{B. Metode}

Penelitian ini termasuk penelitian tindakan kelas (classroomaction research). Tindakan yang dilakukan selama proses penelitian yang di lakukan oleh siswa kelas VII K SMP Negeri 5 Kendari adalah menggunakan media berbasis ICT seperti laptop, gadget, dan printer pada pembelajaran matematika pada materi Memahami Jenis dan Sifat Segi Empat. Penelitian ini dilaksanakan di SMP Negeri 5 Kendari pada tahun pelajaran 2018/2019, khususnya siswa kelas VII K yang berjumlah 30 siswa terdiri dari 16 siswa perempuan 
dan 14 siswa laki-laki yang memiliki latar belakang sosial, ekonomi, budaya, jenis kelamin, serta kemampuan kognitif, afektif dan psikomotor yang berbeda-beda.

Penelitian ini berlangsung selama 2 (dua) bulan, mulai dilaksanakan pada bulan Maret dan berakhir pada bulan April 2019. Waktu pelaksanaan penelitian terdiri dari (1) Persiapan penelitian dimulai dari minggu ketiga bulan Maret dan berakhir minggu pertama bulan April 2019; (2) 2 . Pelaksanaan penelitian terbagi atas 2 (dua) pertemuan yaitu: a) pertemuan pertama, hari Sabtu tanggal 13April 2019 dan (b) pertemuan kedua, hari Kamis tanggal 18April 2019; (3) Pengolahan data dan pembuatan laporan bulan April 2019.

Hal-hal yang diamati pada penelitian ini antara lain (1) variabel output, yaitu hasil belajar siswa merupakan indikasi dari keberhasilan penelitian ini dan (2) Variabel proses pembelajaran, yaitu proses yang terjadi dalam pembelajaran yang meliputi kemampuan guru mengelola pembelajaran dan aktivitas siswa dalam kegiatan pembelajaran.

Sumber data penelitian ini adalah siswa kelas VII K SMP Negeri 5 Kendari dan jenis data yang didapatkan adalah data kuantitatif dan data kualitatif yang diperoleh dari lembar observasi aktivitas siswa, nilai tugas proyek kelompok belajar serta tes hasil belajar siswa.

Cara pengambilan data penelitian yaitu (1) data hasil belajar siswa diambil dengan memberikan tes evaluasi; (2) data aktivitas siswa diambil dengan menggunakan lembar observasi siswa; (3) data kegiatan siswa dalam kelompok belajar diambil dengan menggunakan portofolio; dan (4) data tanggapan siswa diambil dengan menggunakan angket.

Data kemampuan pemahaman konsep divalidasi melalui instrumen tes dan proses pembelajaran yang divalidasi melalui triangulasi sumber dan metode.

Teknik analisis data dilakukan secara deskriptif kualitatif. Analisis deskriptif digunakan untuk mendeskripsikan efektifitas penggunaan media pembelajaran Laga Printer serta untuk menghitung persentase jumlah siswa yang berhasil dalam pembelajaran tersebut. Pelaksanaan penelitian 
siswa dikatakan berhasil (tuntas) apabila hasil belajar siswa mencapai KKM yang telah ditetapkan yakni 75 .

Analisis kualitatif dilakukan dengan metode alir. Menurut Milles dan Huberman (1984), alur yang dilalui meliputi reduksi data, penyajian data, dan penarikan kesimpulan atau verifikasi. Reduksi data adalah proses pemilihan, pemusatan perhatian pada penyederhanaan dan transformasi data kasar yang muncul dari catatan-catatan tertulis di lapangan. Kegiatan ini mulai dilakukan dalam setiap pasca tindakan dilaksanakan. Penyajian data dilakukan dalam rangka pemahaman terhadap sekumpulan informasi yang memberi kemungkinan adanya penarikan kesimpulan. Penarikan kesimpulan dilakukan secara bertahap untuk memperoleh derajat kepercayaan yang tinggi. Dengan demikian langkah analisis data dalam penelitian tindakan ini dilakukan semenjak tindakan-tindakan dilaksanakan.

Data angket tanggapan siswa pada dianalisis menggunakan rating scala dengan kriteria Sangat Baik $=4$, Baik $=3$, Kurang Baik $=2$ dan Tidak Baik $=1$. Data yang telah diberi skor kemudian dikonversikan ke dalam persentase sebagai berikut.

$$
\begin{aligned}
& \mathrm{K}=\mathrm{NiN} \times 100 \% \\
& \text { Keterangan: } \\
& \mathrm{K} \quad=\text { Persentase skor yang diperoleh } \\
& \sum_{\mathrm{Ni}} \mathrm{=} \text { Jumlah skor yang diperoleh } \\
& \mathrm{N} \quad=\text { Jumlah skor maksimal }
\end{aligned}
$$

Hasil perhitungan dimasukkan dalam tabel persentase sesuai dengan kriteria ketetapan seperti pada tabel 1 berikut.

Tabel 1. Kriteria Hasil Angket Siswa

\begin{tabular}{|l|l|}
\hline \multicolumn{1}{|c|}{ Interval } & \multicolumn{1}{c|}{ Kriteria } \\
\hline $81,25 \%<$ skor $\leq 100 \%$ & Sangat Baik \\
\hline $62,50 \%<$ skor $\leq 81,25 \%$ & Baik \\
\hline $43,75 \%<$ skor $\leq 62,50 \%$ & Kurang Baik \\
\hline $25 \%<$ skor $\leq 43,75 \%$ & Tidak Baik \\
\hline
\end{tabular}

Indikator keberhasilan pada penelitian ini adalah (1) indikator keberhasilan yang berkaitan dengan peningkatan prestasi belajar siswa, jika Kriteria Ketuntasan Minimal (KKM) siswa mencapai 75\% setiap siswa 
maka berarti tuntas secara individual, (2) jika Kriteria Ketuntasan Minimal (KKM) siswa 80\% secara keseluruhan maka berarti tuntas secara klasikal.

\section{Hasil dan Pembahasan}

\section{Hasil}

Data respon siswa terhadap penggunaan Laga Printer dalam proses pembelajaran pada materi Memahami Jenis dan Sifat Segi Empat diambil dengan pemberian angket. Berdasarkan data hasil pemberian angket kepada siswa diperoleh data terdapat 25 siswa $(83,33 \%)$ dengan kriteria sangat baik, 3 siswa (10,00\%) dengan kriteria baik, 2 siswa (6,66\%) dengan kriteria kurang baik dan tidak ada siswa yang menyatakan bahwa tidak baik. Data keterampilan siswa diambil dengan menggunakan lembar pengamatan. Hasil pengamatan keterampilan siswa diperoleh data terdapat sebanyak 19 siswa (63,33\%) kategori sangat mahir, 7 siswa (23,33\%) kategori mahir, 1 siswa (3,33\%) kategori kurang mahir dan 3 siswa $(10,00 \%)$ kategori tidak mahir.

Data pengetahuan siswa diambil dengan pemberian soal uraian sebanyak 5 nomor. Dari jawaban siswa diperoleh data sebanyak 26 siswa $(86,66 \%)$ memperoleh nilai $\geq 73$ dan 4 siswa $(13,33 \%)$ memperoleh nilai < 73. Hasil kerja dari 6 (enam) kelompok belajar siswa berupa tugas proyek yaitu kumpulan foto benda-benda di sekitar siswa berbentuk segi empat berdasarkan hasil penilaian dengan kategori sangat baik sebanyak 4 kelompok dan kategori baik sebanyak 2 kelompok.

Analisis kepraktisan media Laga Printer dapat dilihat dari angket yang telah diisi oleh siswa selaku pengguna produk. Angket tersebut disusun dalam skala Likert menggunakan pernyataan positif dan negatif sesuai dengan pendapat Sudjana (2005) sehingga pernyataan positif memperoleh bobot tertinggi dengan rincian sebagai berikut.

a. Sangat setuju dengan bobot 4

b. Setuju dengan bobot 3

c. Kurang setuju dengan bobot 2

d. Tidak setuju dengan bobot 1 
Pemberian nilai kepraktisan dengan cara berikut.

Nilai Praktikalitas $=$ skor yang diperolehskor tertinggi $\times 100 \%$

Hasil yang diperoleh diinterpretasikan dengan menggunakan kriteria seperti pada tabel 2 berikut.

Tabel 2. Kriteria Kepraktisan Media "laga printer"

\begin{tabular}{|c|l|}
\hline Nilai ( dalam \% ) & \multicolumn{1}{|c|}{ Penilaian } \\
\hline $0-54$ & Sangat tidak praktis \\
\hline $55-64$ & Tidak praktis \\
\hline $65-79$ & Praktis \\
\hline $80-100$ & Sangat praktis \\
\hline
\end{tabular}

Media pembelajaran Laga Printer dikatakan praktis penggunaannya apabila diperoleh hasil jika $\geq 70$.

Salah satu karakter bangsa yang perlu dilestarikan adalah kemampuan bekerjasama. Sebab kerja sama adalah jiwa dari gotong royong yang merupakan nilai luhur dan ciri khas bangsa Indonesia. Dengan pembelajaran menggunakan media pembelajaran Laga Printer karakter kerjasama siswa yang dilihat dari tiga indikator yakni ( 1) keaktifan dalam kelompok, (2) kemampuan tanya jawab dalam diskusi kelompok siswa VII K dapat berkembang dan juga mengalami peningkatan, dan (3) kemampuan siswa menggunakan laptop, gadget, dan printer dalam menyelesaikan tugas yang diberikan.

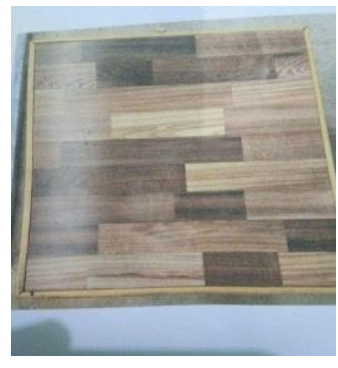

Gambar 1. persegi

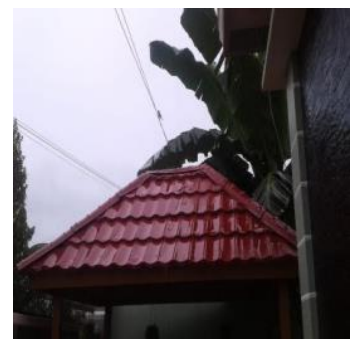

Gambar 4: trapesium
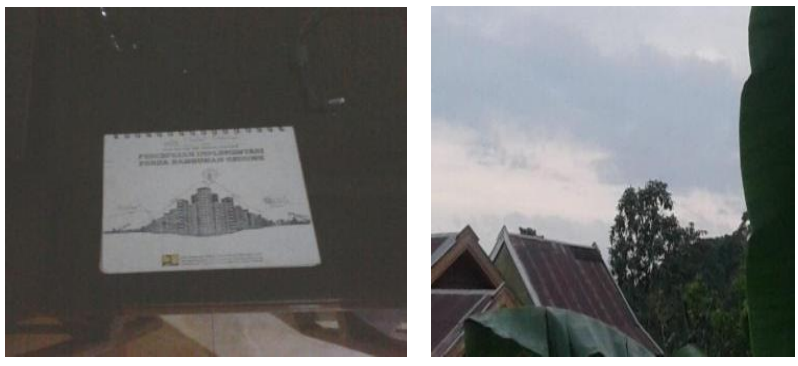

Gambar 2. persegi panjang Gambar 3. jajargenjang
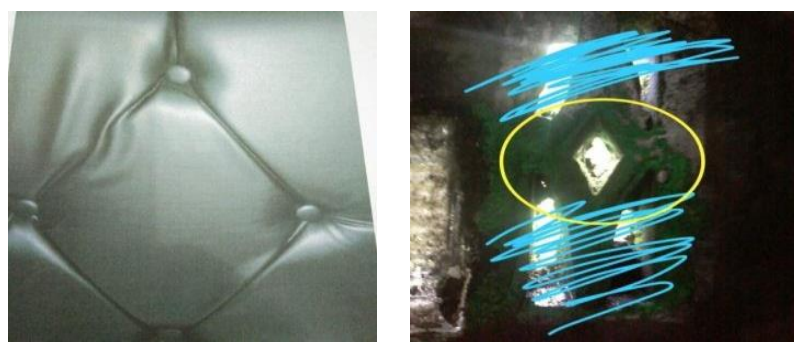

Gambar 5: belah ketupat Gambar 6: layang-layang 


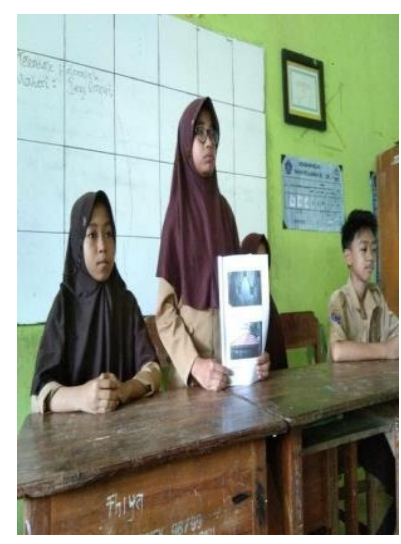

Gambar 7: Presentasi kelompok

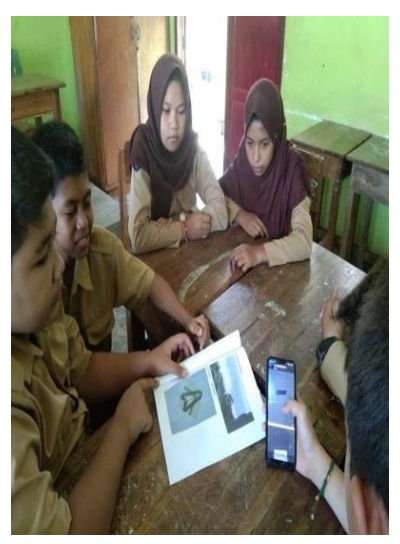

Gambar 8: Diskusi kelompok Gambar 9: Presentasi kelompok

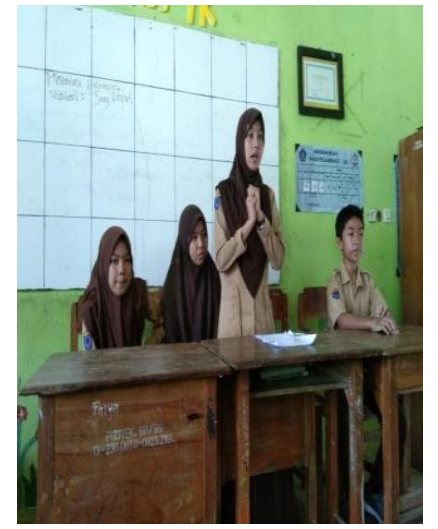

\section{Pembahasan}

Alat bantu bantu pembelajaran untuk mencapai tujuan pembelajaran yang diharapkan oleh guru adalah memanfaatkan perangkat teknologi informasi dan komunikasi yang telah di miliki moleh siswa kelas VII K di SMP Negeri 5 Kendari. Berdasarkan data yang diperoleh, dari 30 orang siswa yang telah memiliki laptop/komputer di rumahnya sebanyak 24 orang $(80,00 \%)$ dan tidak memiliki laptop atau komputer sebanyak 6 orang (20,00\%). Jumlah siswa yang memiliki gadget android sebanyak 22 orang $(73,33 \%)$ dan gadget nonandroid 3 orang $(10,00 \%)$ dan tidak memiliki gadget sebanyak 5 orang (16,67\%). Jumlah siswa di kelas VII K SMP Negeri 5 Kendari yang telah memiliki printer sebanyak 17 orang $(56,67 \%)$.

Namun pada kenyataannya proses pembelajaran matematika di SMP Negeri 5 Kendari belum dapat berjalan secara optimal. Pembelajaran matematika cenderung text book oriented, teacher oriented, dan kurang terkait dengan kehidupan sehari-hari siswa. Pembelajaran cenderung abstrak, sehingga konsep-konsep akademik sulit dipahami. Akibatnya, hasil belajar matematika belum sesuai harapan. Hasil ulangan yang memenuhi KKM atau $48,15 \%$ siswa yang tuntas. Karakter bangsa yang diharapkan juga belum sesuai dengan indikator yang diharapan. Penyebabnya adalah guru belum mampu memanfaatkan media pembelajaran berbasis teknologi informasi (TI) dan media pembelajaran lainnya dengan baik.

Berdasarkan data tersebut, guru berpikir bahwa untuk mengajarkan materi segiempat dengan memanfaatkan perangkat laptop, gadget, dan 
printer yang telah dimiliki moleh siswa dengan cara guru membagi 6 (enam) kelompok belajar dan setiap kelompok belajar beranggotakan 5 (lima) orang siswa. Tujuan yang diharapkan dari pembentukan kelompok agar siswa yang tidak memiliki laptop, gadget maupun printer dapat belajar Bersamasama dengan temannya yang telah memiliki dan dapat belajar bersama dalam menyelesaikan tugas kelompok yang diberikan oleh guru. Ratumanan (2004) menyatakan bahwa seseorang dikatakan belajar bila dapat mengalami perubahan tingkah laku. Perubahan tingkah laku disertai usaha orang tersebut berdasarkan pengalaman yang dialaminya dengan orang lain.

Penelitian Francis M. Dwyer (dalam Mampuono, 2010) menyatakan bahwa setelah lebih dari tiga hari pada umumnya manusia dapat mengingat pesan yang disampaikan dengan: tulisan $10 \%$, pesan audio $10 \%$, visual $30 \%$, audio visual $50 \%$, audio visual dan melakukan $80 \%$. Menganalisa dari hasil penelitian tersebut, maka pembelajaran dengan melibatkan audio, visual, dan melakukan paling mempunyai peluang besar dalam menciptakan pembelajaran yang bermakna. Ini dapat terwujud apabila ada kreasi dan inovasi media dalam strategi pembelajaran. Sebab inovasi media pembelajaran akan membantu proses pembelajaran lebih efektif, efesien, interaktif, menyenangkan, dan memotivasi peserta didik untuk berpartisipasi aktif.

Faktor strategi dan pendekatan yang diterapkan oleh guru pada materi pelajaran tertentu berpengaruh signifikan terhadap peningkatan kemampuan siswa dan aktivitas siswa selama mengikuti proses pembelajaran. Jika guru menerapkan pembelajaran tanpa menggunakan media pembelajaran serta peran guru dalam pembelajaran bersifat sentralistik maka akan menyebabkan siswa pasif, siswa menjadi kurang tertarik terhadap materi pelajaran yang diajarkan, tidak menumbuhkembangkan rasa ingin tahu siswa terhadap materi yang dipelajari, siswa cepat merasa bosan dan berharap proses pembelajaran segera berakhir.

Akan berbeda kejadiannya jika guru menerapkan media pembelajaran di dalam proses pembelajaran. Siswa merasa senang berada di dalam kelas, siswa akan tertarik mengikuti proses pembelajaran, ada rasa ingin tahu terhadap materi pelajaran yang hendak dipelajari serta siswa memiliki motivasi belajar yang tinggi pula. 
Selain itu, hal ini juga diduga disebabkan karena adanya pendekatan saintifik, sebab pendekatan ini menerapkan nilai-nilai atau sifat-sifat ilmiah yang sangat mendukung dalam proses pembelajaran. Nilai-nilai atau sifat-sifat ilmiah itu antara lain (a) kegiatan mengamati bertujuan agar pembelajaran berkaitan erat dengan konteks situasi nyata yang dihadapi dalam kehidupan sehari-hari, (b) kegiatan menanya dilakukan sebagai salah satu proses membangun pengetahuan siswa dalam bentuk konsep, prinsip, prosedur, hukum dan teori, hingga berpikir metakognitif, bertujuan agar siswa memiliki kemampuan berpikir tingkat tinggi (critical thinking skill) secara kritis, logis dan sistematis; (3) kegiatan mencoba bermanfaat untuk meningkatkan keingintahuan siswa untuk memperkuat pemahaman konsep dan prinsip serta prosedur dengan mengumpulkan data, mengembangkan kreatifitas, dan keterampilan kerja ilmiah, (4) kegiatan mengasosiasi bertujuan untuk membangun kemampuan berpikir dan bersikap ilmiah, dan (5) kegiatan mengomunikasikan adalah sarana untuk menyampaikan hasil konseptualisasi dalam bentuk lisan, tulisan, gambar/ sketsa, diagram, atau grafik (Kemendikbud, 2014).

Minat dan motivasi siswa mengikuti pelajaran begitu antusias. Hal ini ditunjukkan dengan jumlah kehadiran siswa didalam kelas $100 \%$ bila dibandingkan dengan pelaksanaan pembelajaran yang tidak menggunakan media pembelajaran. Berdasarkan analisa penulis, antusias nya siswa diakibatkan oleh siswa merasa senang mengikuti pelajaran. Hal ini didukung pula hasil pemberian angket yang diberikan kepada siswa di mana diperoleh data terdapat sebanyak 25 siswa (83,33\%) dengan kriteria sangat baik, 3 siswa $(10,00 \%)$ dengan kriteria baik, 2 siswa $(6,66 \%)$ dengan kriteria kurang baik dan tidak ada siswa yang menyatakan tidak baik. Dari data tersebut jelaslah bahwa siswa memiliki motivasi dan minat yang tinggi serta siswa merasa puas ketika mereka mengikuti proses pembelajaran pada materi Memahami Jenis dan Sifat Segi Empat.

Motivasi dan minat siswa yang begitu tinggi mengikuti pelajaran, berimbas pula pada kemampuan keterampilan dan pengetahuan siswa. Siswa begitu terampil memanfaatkan Laga Printer untuk menyelesaikan tugas kelompok yang diberikan oleh guru. Analisis data terlihat dari hasil pengamatan keterampilan siswa diperoleh data terdapat sebanyak 19 siswa 
$(63,33 \%)$ kategori sangat mahir, 7 siswa $(23,33 \%)$ kategori mahir, 1 siswa $(3,33 \%)$ kategori kurang mahir dan 3 siswa (10,00\%) kategori tidak mahir.

Analisis data menunjukkan bahwa kemahiran siswa mengggunakan media Laga Printer tersebut disebabkan oleh siswa sudah memiliki dan pernah mengoperasikan media tersebut di dalam kehidupan sehari-hari. Siswa tidak merasa canggung dalam mengoperasikan media tersebut di dalam menyelesaikan tugas yang diberikan oleh guru untuk diselesaikan secara kelompok. Hasil kerja dari 6 (enam) kelompok belajar siswa berupa tugas proyek yaitu kumpulan foto benda-benda disekitar siswa berbentuk segi empat berdasarkan hasil penilaian dengan kategori sangat baik sebanyak 4 kelompok dan kategori baik sebanyak 2 kelompok.

Begitu pula dengan aspek pengetahuan, ketika siswa di berikan soalsoal evaluasi berbentuk soal uraian sebanyak 5 nomor. Dari jawaban siswa diperoleh data sebanyak 26 siswa $(86,66 \%)$ memperoleh nilai $\geq 73$ dan 4 siswa $(13,33 \%)$ memperoleh nilai $<73$. Dari analisis data menununjukkan bahwa siswa telah meningkat pemahaman dan kemampuannya mengikuti pelajaran pada materi Memahami Jenis dan Sifat Segi Empat. Meningkatnya pemahaman siswa disebabkan oleh berfungsinya Laga Printer dalam proses pembelajaran. Karena penggunaan media pembelajaran salah satu fungsinya adalah media dapat memberikan informasi atau pesan kepada penerimanya dalam hal ini siswa. Media pembelajaran berbasis ICT dapat menghasilkan pembelajaran yang lebih bermakna di dalam kehidupan siswa. Hal ini ditunjukkan dengan nilai praktikalitas "laga printer" dengan nilai 78 dengan penilaian Praktis.

Berdasarkan kurikulum 2013 di semester genap tahun pelajaran 2018/2019, materi pokok bahasan Segi Empat dan Segi Tiga dipelajari oleh siswa kelas VII. Materi pada pokok bahasan Segi Empat dan Segi Tiga sub pokok bahasan Memahami Jenis dan Sifat Segi Empat hasil dari Musyawarah Guru Mata Pelajaran dilaksanakan di bulan April 2019.

Berdasarkan analisis materi pelajaran yang hendak diajarkan kepada siswa, guru menerapkan pembelajaran dengan menggunakan media pembelajaran berbasis ICT dengan memberikan tugas kepada siswa untuk diselesaikan secara kelompok. Tugas tersebut adalah siswa mendokumentasikan 
benda-benda di sekitar siswa yang termasuk segi empat seperti persegi, persegi panjang, jajaran genjang, trapesium, belah ketupat, dan layang-layang.

Hasil kerja siswa tersebut berupa laporan yang berisi foto bendabenda yang termasuk Segi Empat untuk di presentasikan di depan kelas oleh masing-masing kelompok. Ketika siswa mempresentasikan hasil kerja kelompoknya, guru berperan sebagai fasilitator dan motivator. Kegiatan pembelajaran terpusat pada siswa (student centered). Kegiatan siswa tersebut didokumentasikan dalam bentuk foto-foto serta video pembelajaran dan guru menginformasikan kegiatan siswa tersebut kepada rekan guru sejawat khususnya guru matematika di lingkup SMP Negeri 5 Kendari.

\section{Penutup}

Dari paparan data, deskripsi dan analisis hasil pembelajaran yang telah diuraikan sebelumnya, maka ditarik kesimpulan sebagai berikut.

1. Data kuantitatif berupa aspek keterampilan (psikomotorik) siswa yaitu diperoleh data terdapat sebanyak 19 siswa $(63,3 \%)$ kategori sangat mahir, 7 siswa (23,4\%) kategori mahir, 1 siswa $(3,3 \%)$ kategori kurang mahir dan 3 siswa (10,0\%) kategori Tidak Mahir. Pada aspek pengetahuan (kognitif) diperoleh data sebanyak 26 siswa $(86,7 \%)$ memperoleh nilai $\geq 73$ dan 4 siswa $(13,2 \%)$ memperoleh nilai $<73$.

2. Data kualitatif yaitu tingkat kepuasan siswa terhadap penggunaan Laga Printer dalam proses pembelajaran diperoleh data terdapat sebanyak 25 siswa $(83,3 \%)$ dengan kriteria sangat baik, 3 siswa $(10,0 \%)$ dengan kriteria baik, 2 siswa (6,7\%) dengan kriteria kurang baik dan tidak ada siswa yang menyatakan tidak Baik. Kepraktisan Laga Printer terhadap siswa dapat ditunjukkan dengan nilai praktikalitas dengan nilai 78 dengan penilaian Praktis.

Berkenaan dengan hasil penelitian, maka dikemukakan saran antara lain (a) Karena pembelajaran dengan penggunaan Laga Printer mampu membelajarkan dan meningkatkan hasil belajar siswa maka disarankan kepada para guru matematika agar menerapkan media ini pada materi 
Memahami Jenis dan Sifat Segi Empat atau materi matematika yang lainnya; Para gurudisarankan agar dalam pembelajaran matematika memanfaatkan realita dan lingkungan yang dipahami oleh siswa dengan memanfaatkan alat-alat berbasis ICT seperti laptop, gadget dan printer sebagai media pembelajaran, (2) Guru hendaknya tidak memberikan bantuan secepatnya kepada siswa dalam menyelesaikan masalah yang diberikan, tetapi menerapan cara mengajar yang mampu mengaktifkan siswa dalam belajar misalnya dengan menggunakan pendekatan realistic, (c) Sebagai bahan masukan bagi rekan guru sejawat pada kelompok Musyawarah Guru Mata Pelajaran Matematika (MGMP) SMP Tingkat Kota Kendari Provinsi Sulawesi Tenggara, agar menindak lanjuti hasil penelitian ini dengan cara melakukan penelitian selanjutnya demi pengembangan media dan meningkatkan kualitas pendidikan di sekolah.

\section{Ucapan Terima Kasih}

Alhamdulillah pelaksanaan penelitian telah selesai dan ucapan terima kasih di tujukan kepada berbagai pihak yang telah membantu selama pelaksanaan penelitian baik pada tahapan perencanaan, pelaksanaan, pengamatan, pengolahan data-data serta penyusunan laporan penelitian. Secara khusus ucapan banyak terimakasih yang tak terhingga kepada kepala SMP Negeri 5 Kendari bapak Muh. Nurdin, S.Pd., M.Pd., yang telah memberikan bantuan baik bantuan berupa materi maupun materiil berupa motivasi, Bapak La Muli, M.Pd., yang telah membantu selama penelitian, serta rekan-rekan guru di SMP Negeri 5 Kendari. Terima kasih pula ditujukan kepada siswa kelas VII.K SMP Negeri 5 Kendari yang berperan aktif dan antusias selama berlangsungnya pembelajaran di kelas.

\section{Daftar Referensi}

Azhar, Arsyad. (2002). Media Pembelajaran. Jakarta: Raja Grafindo.

Diba, F. Zulkardi \& Saleh, T. (2009). Pengembangan Materi Pembelajaran Bilangan Berdasarkan Pendidikan Matematika Realistik untuk Siswa Kelas V Sekolah Dasar. Jurnal Pendidikan Matematika. Vol. 3 (1) : $33-46$. 
Fonna, M., \& Mursalin, M. (2018). Role of Self-Efficacy Toward Students' Achievement in Mathematical Multiple Representation Ability (MMRA). Jurnal Ilmiah Peuradeun, 6(1), 31-40. doi:10.26811/peuradeun.v6i1.174

Hudoyo. Herman. (1990). Belajar Mengajar Matematika. Jakarta: Depdikbud.

Kemendikbud. (2014). Peraturan Menteri Pendidikan Nasional Republik Indonesia Nomor 41 Tahun 2007 Tentang Standar Proses untuk Satuan Pendidikan Dasar dan Menengah. Jakarta: Kemendikbud.

Mampuono. 2010. "Multimedia Pembelajaran". Semarang: LPMP.

Ratumanan, T.G. (2004). Belajar dan Pembelajaran. Surabaya: UNESA University Press.

Ruseffendi, E.T. (1992). Pengajaran Matematika Modern. Bandung: Tarsito.

Sodiq, Fadjar. 2009. PentingnyaMatematika dalam Kehidupan. Yogjakarta: LIMAS PPPPTK Matematika

Sudjana, Nana, \& Rivai, Ahmad (2005). Teknologi Pengajaran. Bandung: Sinar Baru Algesindo.

Suryani, N. (2015). Pengembangan Media Pembelajaran Berbasis IT. Prosiding Workshop Nasional: Pengembangan ICT dalam Pembelajaran, 1-13.

Vitoria, L., \& Monawati, M. (2016). Improving Students' Problem Solving Skill in Mathematics Through Writing. Jurnal Ilmiah Peuradeun, 4(2), 231-238. doi:10.26811/peuradeun.v4i2.100

Zimmerman, B.J. (2005). Handbook of Competence and Motivation. Edited by Andrew J Eliot and Carol S Dweck. The Guilford Press. New York. 